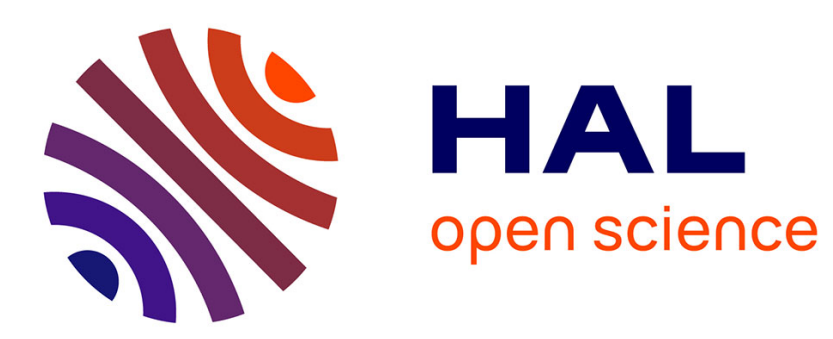

\title{
On the mirative meaning of aller + infinitive compared with its equivalents in English
}

\author{
Agnès Celle, Laure Lansari
}

\section{To cite this version:}

Agnès Celle, Laure Lansari. On the mirative meaning of aller + infinitive compared with its equivalents in English. Cahiers Chronos, 2015, Taming the TAME systems, 27, pp.289-305. hal-01833733

\section{HAL Id: hal-01833733 \\ https://hal-univ-paris.archives-ouvertes.fr/hal-01833733}

Submitted on 5 Dec 2019

HAL is a multi-disciplinary open access archive for the deposit and dissemination of scientific research documents, whether they are published or not. The documents may come from teaching and research institutions in France or abroad, or from public or private research centers.
L'archive ouverte pluridisciplinaire HAL, est destinée au dépôt et à la diffusion de documents scientifiques de niveau recherche, publiés ou non, émanant des établissements d'enseignement et de recherche français ou étrangers, des laboratoires publics ou privés. 


\title{
On the mirative meaning of aller + infinitive compared with its equivalents in English
}

\author{
Agnès CELLE, Laure LANSARI, \\ Université Paris Diderot, Sorbonne Paris Cité, CLILLAC-ARP EA 3967
}

\section{Introduction ${ }^{1}$}

In the linguistic literature devoted to aller + infinitive in French, a specific meaning has been identified and labelled "allure extraordinaire" by Damourette and Pichon (1936: 429), which we translate using the term "mirative meaning". The following example illustrates this meaning: ${ }^{2}$

(1) Il a désigné dans le désordre nos confrères Bastide, Cormier, Besson, Mitchea et votre serviteur. On se demande où il est allé chercher cela et s'il ne nous soupçonne pas d'écrire sur des feuilles de vigne. (Frantext, Blondin Antoine, Ma vie entre les lignes, 1982: 450)

(1') [...]. We wonder where he picked up that idea [...]

Aller does not have its spatial meaning in (1) since no motion is involved. Nor does it refer to a future event. According to Damourette and Pichon, aller is used to signal that the event referred to does not correspond to the speaker's expectations ("dans ce tour le verbe aller confère au verbe dont l'infinitif le suit un caractère dérangeant par rapport à l'ordre attendu des choses" (ibid.)). The speaker expresses surprise at what the character did and explicitly disapproves of this event. We argue that this meaning may be subsumed under the semantic category defined in linguistic typology as mirativity - a category encoding "information $[. .$.$] new or unexpected to the$ speaker" (DeLancey, 2001), "unexpected perception" (Lazard, 2001) or "surprising facts" (Guentchéva, 1996).

Mirativity is seen either as a category of its own (see DeLancey) or as a subcategory of evidentiality (see Guentchéva, Lazard). For Guentchéva and Lazard, evidentiality deals with the marking of three related meanings hearsay, inference and surprise. In some languages, evidentiality is

1 We wish to express our gratitude to the anonymous reviewer who has allowed us to bring to this paper much needed changes and clarifications. Any remaining errors or shortcomings are ours entirely.

2 The translations are ours. They are to be taken as glosses. 
grammaticalised into a full-fledged linguistic system, but, as pointed out by many authors, there is no such grammaticalised evidential system in French and English: in these two languages, evidentiality - and henceforth mirativity - exists only as a "covert semantic category" (DeLancey, 2001). In other words, mirative meaning is expressed in an unsystematic way by linguistic items whose overt function is not that of encoding mirativity.

DeLancey claims that intonation is one of these devices, and we argue that verbal constructions involving aller and go might be another. We contend more precisely that, in the case of aller and go, surprise or unexpectedness is very often associated with a negative evaluative judgement. We also aim to show that mirativity intersects with the lexical aspect of an event. In French, aller + infinitive introduces a comment on the initial boundary. In English, a range of aspectual shades of meaning are conveyed by different go-constructions. We focus on go $V$-ing and on the binomial phrase go and $V$.

\section{Mirative aller}

\subsection{Judgement on past and current states or events}

Mirativity usually has to do with past and current events or states (see for instance Guentchéva's analysis of the French "passé composé"). In (1), the speaker first states what happened in a neutral way, then comments on the past event, marking it as both surprising/unexpected and undesirable. Unexpectedness is inherently epistemic, an unexpected event being typically thought to be unlikely. In addition, unexpectedness impinges on the speaker's appraisal. ${ }^{3}$ The speaker looks back on an event that is considered unlikely in

3 Rocq-Migette (2009: 228-229) points out that the adjectives surprised and surprising express epistemic modality when followed by an if-clause. Although these predicates primarily convey attitudinal modality, she explains that their epistemic reading is due to the nature of surprise: "The concept to which surprise refers belongs to the category of emotions and feelings; but contrary to happiness or sadness which are purely emotive, surprise is created by something which is external to the speaker. I am surprised cannot be used without a situational or textual context giving the source of the feeling.[...] With ifclauses and presupposition expressing 'contrary to expectation', the status of the event, as assessed by the speaker, comes to the foreground. The prediction feature becomes central in the information which is imparted". She also notes 
retrospect, as on se demande shows. Mirative aller is indeed frequently associated with epistemic elements:

(2) Que le motif du crime ne soit pas le vol, il est - au sens exact des mots "payé pour le savoir ». Mais pourquoi aller imaginer ce dédoublement de l'assassin? (Frantext, Robbe-Grillet Alain, Les Gommes, 1952: 225)

(2') [...]. But why would he make up a second murderer?

Besides this epistemic component, mirative aller very often involves a negative evaluative judgement whereby the event is regarded as undesirable/abnormal. Although Bres \& Labeau (2012) claim that mirative aller may express either a negative deontic evaluation or an epistemic judgment, we contend that the epistemic component is present in all instances of mirative aller. Indeed, surprise is inherently epistemic since it marks a discrepancy between what is expected and what is, or might be, the case. More often than not, this discrepancy is considered undesirable by the speaker. Bres \& Labeau only give few instances where the speaker's surprise does not overlap with negative evaluation. Here is one of them:

(3) Je vais te raconter quelque chose qui va te faire rire je sais pas comment je suis allée penser au papet et à cette fois je sais pas si tu t'en rappelles [...]/ je sais pas pourquoi je suis allée penser à ça

(3') I'm gonna tell you something that's gonna make you laugh I have no idea why I started thinking of Grandpa and at that time I don't know if you remember [...] / I have no idea why it crossed my mind

It should be stressed, however, that a negative component is present even in such examples, where aller + infinitive appears in a complement clause dependent on the main clause predicate je ne sais pas comment/pourquoi. The event is thereby presented as resisting any rational explanation. Negative evaluation is most striking in the following example:

(4) Oui, une voiture toute neuve. Et ce connard est allé m'emboutir une aile ! (quoted by Larreya, 2005: 351).

(4') Yes, it was a brand new car. And that silly bugger ran into a wing!

that the presence of adjectives such as likely or unlikely in the contextual environment corroborates the epistemic interpretation. 
In other instances, the starting point of the speaker's comment is not a past event but the current state of affairs - the addressee's illness in the following example:

(5) C'est pas vrai... T'es malade - où t'es allé attraper ça ? (quoted by Larreya 2005: 354)

(5) It can't be true... Don't tell me you're ill - where did you catch that?

When faced with the news that will probably ruin his/her plans, the speaker first expresses surprise (c'est pas vrai) and then tries to infer what has caused the current state of affairs, using aller in the "passé composé". As is often the case in languages that have evidential systems (see DeLancey, 2001), inference and mirativity appear here to be entangled. Unexpected events naturally lead speakers to try to find a plausible cause for them.

When the event or state commented on is actualised at the time of utterance, mirative aller is used as a "constative" (see Larreya, 2005). A comment is made about an actualised event, that is to say about an event denoted by a proposition which may be either true or false (i.e. either he is ill or not). In retrospect, the speaker indicates that the actualisation was unlikely and s/he points out its annoying consequences in the speech situation. This operation of reasoning is called abduction by Peirce (1998: 287). Peirce stresses that surprise triggers abduction: "A peculiar state of facts [is suggested] that will 'explain' the surprising phenomenon; and a law already known is recognized as applicable to the suggested hypothesis, so that the phenomenon, under that assumption, would not be surprising, but quite likely, or even would be a necessary result. This synthesis suggesting a new conception or hypothesis is the Abduction." Interestingly, Peirce also points out that the conclusion is not asserted, but "drawn in the interrogative mood"

\subsection{Judgement on anticipated events}

Mirative aller is not only compatible with the "passé composé", but may be used with a variety of tenses and moods (see examples below). In this respect, it differs greatly from temporal aller + infinitive, which can only be used in the present tense and the "imparfait". Mirative aller actually seems to have retained the morphosyntactic characteristics of the motion verb, which is unconstrained in terms of tense and mood, in contrast to the auxiliary used to refer to the future. We follow Larreya (2005: 354), who claims that the 
morphosyntactic similarity between mirative aller and spatial aller is evidence that the mirative meaning has directly developed from the motion verb, not from the future meaning.

This temporal flexibility explains the manifold uses of mirative aller. The construction may express the speaker's disapproval of past, current, as well as anticipated events:

(6) Je connaissais l'histoire, mais de seconde voix. Il a tenu à me donner la version exacte... que j'aille pas me figurer n'importe quoi. (Frantext, Boudard Alphonse, Les Enfants de choeur, 1982: 95)

(6') I knew the story, but as second hand information. He insisted on telling me the accurate version... so that I wouldn't start imagining things.

(7) Allons, voyons, tu es assez copain avec moi pour me parler franchement. $T u$ ne vas pas me dire que tu tiens à rester dans cette boîte pour ton plaisir. (Frantext, Clavel Bernard, La Maison des autres, 1962: 160)

(7') Come on, we're friends, you can speak frankly. You're surely not going to tell me that you want to stay in that company just for fun.

In (6), the reporting speaker never made up weird imaginings, but the reported speaker had reasonable evidence to believe s/he was probably about to. Similarly, in example (7), the addressee has not claimed he wants to stay in the firm because he likes it there, but the speaker seems to have reason to believe that he will make such a claim. In both (6) and (7), the state of affairs is somehow anticipated and immediately rejected by means of the negative marker because its actualisation would run counter to what the speaker considers normal and desirable behaviour.

Larreya labels these uses "non-constative". Pragmatically speaking, "non-constative" utterances differ from constative ones. They usually involve a negation ${ }^{4}$ because the speaker does not want the event to become reality. His/her "argumentative strategy" (Schrott, 2001) is to contemplate the actualisation only to reject it..$^{5}$ The utterance with aller then serves as an implicit warning to the addressee when an intersubjective relation is at stake, as is the case in example (7) above or in the following instances:

$4 \quad$ See Flydal (1943: 57).

5 The scope of the negation is crucial to disambiguate between futurity and mirativity (see Giancarli, 2006; Larreya, 2005; Schrott, 2001). In the mirative meaning, the negation bears on the proposition as a whole. In the case of future aller, it bears on the link between subject and predicate within the proposition. 
(8) On vous croit mort, fit-il valoir, vous n'avez plus d'existence légale, c'est ce que vous vouliez, non ? Donc, qu'est-ce que je risquerais à vous supprimer ? Tuer un mort n'est pas un crime, supposa-t-il [...]. Allons, dit Delahaye, vous n'allez pas faire ça. Non, reconnut Ferrer, je ne crois pas. (Echenoz, Je m'en vais)

(8) [...]. Come one, Delahaye said, you're not going to do that. [...]

(9) L'homme explique, discute, argumente encore et Michèle Bernard-Requin explose: «Vous n'allez tout de même pas m'apprendre le code ? » lance-telle... (Télérama, June 2004)

(9') [...]. 'You're not teaching me the highway code, are you?' [...]

The speaker's anticipation of a state of affairs s/he deems abnormal works as a powerful incentive for the addressee to change his/her attitude. This "nonconstative" use may thus be labelled "vetative", meaning being implied by the negation.

In examples (8) and (9), it might be difficult to categorise aller + infinitive precisely. It is not clear whether the verbal construction functions as a future marker or as a mirative marker. There might even be some degree of overlap between these two semantic categories. We contend that no real prediction is made, insofar as these utterances are defined by a lack of assertiveness, as reflected by their intonation. Indeed, they are not assertive statements but waver between interrogation and exclamation. The speaker does not really predict the future actualisation of the event. We claim, moreover, that there is some kind of overlap between inference and mirativity, inference serving to reject the future actualisation of the event. ${ }^{6}$ In our sample, the inference is based on situational evidence. In example (8), Ferrer's threatening words progressively lead Delahaye to infer that Ferrer might kill him; although he finds it hard to believe. In (9), the speaker has been watching the man and has the feeling he will soon be teaching her how to do her job.

6 In an attempt to explain different shades of mirative 'extensions', Aikhenvald (2004: 198) argues "one may be surprised at an ongoing process, or at an inference made on the basis of some visible evidence".

7 The gloss with will be-ing proposed here highlights interesting common points between mirative aller and the mirative meaning of will be-ing analysed in Celle \& Smith (2010: 255). With will be-ing, the strategy is different; the speaker does make a prediction aiming "at warning the hearer against the negative and inevitable consequences of his/her behaviour, should no change occur". 
The speaker's anticipation of a new state of affairs gives way to a true order "not to" when aller appears in the imperative:

(10) Abba Cronios reprit pour s'adresser à Macaire le ton railleur qu'il affectionnait:

- Tu as réussi à garder le silence. Ne va pas t'imaginer qu'il y a de quoi être fier. Dis-toi plutôt que tu n'es pas digne de parler. (Frantext, Weyergans François, Macaire le Copte, 1981: 55).

(10') [...]. You managed to remain silent. Don't go thinking you can be proud of it. $[\ldots]$

(11)- T'en as violé combien, toi, des Cambodgiennes?

- Oh, va pas croire... j'ai jamais violé une femme. J'en ai payé avec ma solde, mais ça n'empêchait pas les sentiments. (Frantext, Boudard Alphonse, Les Enfants de choeur, 1982: 152)

(11') - How many Cambodian women did you rape?

- Oh, don't get it wrong... I never raped a woman. [...]

As Bourdin (2003) points out, an aspectual flavour may be perceived here. "Ne va pas t'imaginer" and "va pas croire" roughly correspond to "don't even start thinking". 8

If no negation is involved, the imperative refers to an event whose actualization is pragmatically impossible. There is a sarcastic overtone associated with this use of aller + infinitive:

(12) Va savoir! / Allez travailler avec tout ce vacarme! / Va comprendre, Charles! (quoted by Forest 1999: 61)

(12') Go figure! / Just try and work with all that noise! / Go figure, Charles!

The speaker asks the addressee to do something even though s/he perfectly knows it is undoable. The meaning is still mirative since it would be

8 The same process is at play in some utterances with the subjunctive: Et qu'on n'aille pas dire que ces billets nouveaux sont inoffensifs (Frantext, MendèsFrance Pierre, Oeuvres complètes. 1. S'engager. 1922-1943., 1984: 69) / I won't let anyone tell me that these new notes are harmless! 
surprising if the addressee actually did manage to do what is required of $\operatorname{him} /$ her.

\section{A comparison with two go-constructions in English}

While the motion verb go has been thoroughly studied in its use as a future periphrasis (be going to + infinitive), other constructions involving the nonmotional meaning of $g o$ are less documented. However, go is used in several idiomatic constructions to refer to change of state rather than motion ( $g o$ mad, go missing). In these constructions, go requires $d o$-support in negative and emphatic utterances, as well as in questions, and therefore is not an auxiliary. Clark (1974: 317) argues that go indicates "departure from a normal state", carrying evaluative connotations. ${ }^{9}$ Along the same line of thought, Bourdin (2003: 115) demonstrates that $g o$ functions as a marker of "aspect and modality conjoined" in the go V-ing construction. Our contention is that the binomial phrase $g o$ and $V$ is also a conjoined marker of aspect and evaluative modality in some of its uses. We focus here on go $V$-ing and go and $V$ as markers of evaluative modality, and argue that these two constructions may be regarded as counterparts of mirative aller. However, the aller-construction and the two go-constructions under scrutiny differ in terms of aspect, which explains why the French construction and the English ones are not necessarily translational equivalents.

\subsection{Go V-ing}

Mirative go occurs in contexts where there is no implication of motion. We distinguish between two types of mirative go: $g o \mathrm{~V}$-ing may either refer to an absence following the end of a state of affairs viewed as normal, or to an attitude or activity that should be refrained from. The first use typically involves the verb miss or the motion verb go as complements of go:

(13) But we covered everything you know, steam engines and diesel engines and oh crushers and construction work and development and pneumatic

Paulin (2006) claims as well that go-constructions expressing a change of state are used by the speaker to mark a discrepancy between his/her expectations and what is the case. 
gear, compressors and oh any damn thing that went going. We made everything ourselves more or less. (BNC)

(14) It's my jeep, OK? My driver. I'm not allowed to report the loss by radio, I've got to do it in person. It's a hell of a journey but that's the law. The Lodwar police really like helping citizens in distress. My jeep went missing? Tough shit. (Le Carré, Constant Gardener)

The construction indicates that the referent of the grammatical subject underwent a change of state, being first present and then absent. The presence of the things referred to in (13) and the presence of the jeep in (14) are viewed as normal states, while their absence departs from the normal state of affairs. In this constative use, the speaker is faced not with a new event, but rather with the end of a state of affairs.

The other use of mirative $g o$ marks the speaker's disapproval ${ }^{10}$ of an attitude or an activity which may be either witnessed or feared. In any case, this activity is evaluated negatively:

(15) The markets are in complete disorder, yet they remain unable to solve the situation themselves, and so go looking for a public sector bailout. Risk management, the buzz word of the financial markets since the collapse of Barings Bank in 1995, is clearly an oxymoron. (The Guardian, Friday 19 September 2008)

(16) It is could be called a movement [sic], then it is one which is concerned with feelings rather than rights. It is about men reconciling their feelings towards their fathers and learning how to show emotion. But if the best way to do this is by romping around a campfire and sniffing each other's bottoms is open to question. "A lot of guys go thinking they're going to buy

10 In this, we follow Spears (1982: 866). Spears contrasts the ' $g o$ of disapproval' with the 'come of indignation', which is used as a semi-auxiliary in Black English. The comparison between the itive and ventive markers would go beyond the purpose of this paper. However, it is noteworthy that both English (see Spears) and French (see Bres \& Labeau, 2012) have mirative ventive markers, at least in some of their dialectal variants. Our hypothesis is that the mirative meaning is based on the deictic orientation of these verbs, the event being presented as either departing from the speaker's norm or intruding upon his/her sphere. Indeed, in French venir tends to occur in contexts where the event is seen as impinging on the speaker's world, as in ne venez pas me faire une chute sur le parquet, vous l'abîmeriez (private conversation: don't you fall on the floor, you'd damage it). 
sensitivity," says Richard Bradley, who produced a BBC Forty Minutes documentary about a Wildman weekend shown earlier this year. (BNC)

(17)This woman kept following him, and leaving gifts for him. When she finally confronted him at the stage door, he begged her not to go buying all these gifts. Some time after that he read in the paper that she'd shoplifted all the stuff so he worried he had a lot of stolen goods on his hands. (Fleming, Burnt Piano)

The motional interpretation of $g o$ is not possible in any of these examples. Clearly, go takes on an evaluative function and expresses continuative aspect: in these three examples, go might be paraphrased by keep or keep on. Go signals that the referent of the grammatical subject is already involved in a process in reaction to some disorder as in (15) or as part of some social trend as in (16). In (17), the woman buying gifts corresponds to the current state of affairs and the reported speaker wishes to put an end to it.

As noted by Spears (1982: 866), evaluative go cannot occur in the progressive:

$(15 ') *$ The markets are going looking for a public sector bailout.

(16') *A lot of guys are going thinking they're going to buy sensitivity.

in contrast to motional $g o::^{11}$

(18) How d' you think you're going to feel, Joey, when we come face to face with a herd of elephant or a tawny tiger out there? " " I thought we weren't out to shoot elephants or tigers, " replied Joseph absently. " We're not going looking for them, genius -- but they don't know that, do they? If they come looking for us with tusk and fang you'd better be ready with that Winchester peashooter of yours. " (BNC)

This is a distinguishing feature of evaluative $g o$ and may help disambiguate between the motional and mirative meanings.

At the same time, the event that is evaluated runs counter to the speaker's norm and expectations. In (15), the course of events is viewed as erratic, given the disorder of the markets. In (16), the speaker clearly considers the guys to have a simplistic approach to sensitivity. In (17), as in most of the examples of the sample, the go $V$-ing construction occurs in a

$11\left(15^{\prime}\right)$ and $\left(16^{\prime}\right)$ would imply that the referents of the grammatical subject intentionally look for... or think..., which is incompatible with the inanimate (and thus non-agentive) subject in (15') and with the cognitive state in (16'). 
negative context where the speaker explicitly objects to the process that has been going on.

Mirative go occurs mainly in negative and non-assertive contexts. Typically, the speaker attempts to prevent the course of events from deviating from what $\mathrm{s} / \mathrm{he}$ assumes to be the natural course of things:

(19) "See, I don't want Mrs Hollidaye to go thinking you're riff-raff. I don't want her to go getting any wrong ideas about what's become of me." (BNC)

(20) They want someone who looks as if he's been shot at, wounded, and spent the day crawling through minefields to deliver the dispatches. So don't go looking too neat. On the other hand, don't go looking too battered. (BNC)

(21) You were always good to her, Justin, you know you were. You mustn't go castigating yourself for crimes you didn't commit. A lot of people do that when they lose someone, and they're not being fair on themselves. (Le Carré, Constant Gardener).

The event referred to by the complement of go is evaluated negatively and the speaker wants to avoid or stop its actualisation. Mirative go takes verbs of activity and verbs of cognition as its complements. Even if the verb refers to an uncontrollable state of affairs (what someone thinks, the way someone looks), it is presented as an activity for which the referent of the grammatical subject can be held responsible. In this way, this state of affairs may be criticized by the speaker in an interpersonal exchange.

\subsection{The binomial phrase: Go and $V$}

The binomial phrase is also an exponent of mirativity in some of its uses. As in the $g o V$-ing construction, go may retain its spatial meaning in some cases:

(22) I'll tell you something, why don't you go and invite Carole and Brian? That's what she said. Well I would, I should go up there and have a word with Carole and Brian cos they sit on their own all Christmas virtually! (BNC)

Go up there clearly indicates that a motion is involved. Consequently, two separate events are coordinated in go and invite: the fact of going somewhere and the fact of inviting someone.

However, the structure can also be used to indicate that the event referred to by the conjoined verb is foolish and/or unexpected (see the overview of dictionaries in Collin 2010). There is only one event at stake and go does not denote motion: 
(23) 'I thought she could walk home with some of her friends, and let herself in. Then the silly girl goes and loses her key'. (Coe, The House of Sleep)

(24) Goddamn niggers, Lord. What I have to put up with! Sonuvabitch, I can't figure out what in hell for they went and put niggers in my squad for. (Brown Corpus)

(25) He remembered Nigger Island as a boy. ... sort of rock covered with gullsstood about a mile from the coast. It had got its name from its resemblance to a man's head - a man with negroid lips. Funny idea to go and build a house on it! Awful in bad weather! But millionaires were full of whims! (Christie, Ten Little Niggers)

Example (23) highlights the contrast between the speaker's expectations (I thought she could...) and the event that actually took place. The event was unlikely to happen, and its actualisation is seen as deeply annoying (see the adjective silly). In example (24), the speaker expresses his incredulity (I can't figure out) and his anger at what they did. In (25), the speaker's surprise at the millionaires' whims is clearly stated. Like mirative aller and go V-ing, the binomial phrase thus seems to convey the speaker's epistemic judgement (unexpectedness) and his/her negative evaluation of an event.

In the previous examples, the binomial phrase refers to an actualised event but the construction can also have vetative uses whereby the speaker anticipates an abnormal kind of behaviour in an attempt to avoid its actualisation:

(26) There's your coffee. Now don't go and spill it all over the photos! (BNC)

Both in constative and vetative uses, the binomial phrase is incompatible with verbs denoting a cognitive state. We argue that such a constraint derives from the aspectual properties of the construction, which focuses on the endpoint of the process and on its resultant state (the coffee might be spilled, the key is lost in (23), the house is built in (25), etc.)

From a typological viewpoint, Bybee, Perkins \& Pagliuca (1994: 57-60) mention the existence of languages (e.g. Tucano) where itive markers are used as markers of "completive aspect". Completive aspect is defined by three elements: " 1 . The object of the action is totally affected, consumed, or destroyed by the action [...]. 2. The action involves a plural subject of intransitive verbs or object of transitive verbs. [...]. 3. The action is reported with some emphasis or surprise value". Although no such aspect exists in English, the authors suggest that there might be a completive component in 
go and $V$, "which is usually used in the past to emphasize the deliberateness and finality of an action". We contend that the "finality" of the action may be ascribed to the coordination structure itself. As Collin (2010) argues, go works as the starting point of the process and consequently the second verb is construed as the final step of that process. As a whole, the construction perfectivises a situation. As for the "deliberateness" of the action, we propose to re-examine it in terms of responsibility: even when the binomial phrase does not appear in the past, emphasis is laid on the agent's responsibility, whether the event is actualised or feared.

\section{Concluding remarks: three types of mirativity intermingled with lexical aspect}

We have distinguished between three types of mirative meaning, all of them being entangled with lexical aspect. Mirative aller and go function as modal modifiers, in contrast to the temporal periphrases aller + infinitive and be going to.

a. In the construction with go missing, surprise emerges from the interruption of a state of affairs considered normal. Only the English go $\mathrm{V}$ ing construction may express this meaning.

b. Surprise may result from the speaker witnessing a fact that runs counter to his or her norm. This constative use is common to the three constructions aller + infinitive, go $V$-ing and the binomial phrase go and $V$.

c. A dissonant event may be anticipated in an attempt to prevent it from happening. There is a strong interpersonal quality associated with this vetative use, which is typically found in imperative and/or negative utterances. All the constructions under scrutiny may convey this mirative meaning.

The characteristic feature of constative and vetative mirativity when the grammatical subject is animate is that the speaker does not really comment on a state of affairs but on the origin of that state, that is to say on the referent of the grammatical subject. Moreover, this referent is held responsible for the anticipated or new state of affairs. What is seen as surprising or abnormal is the fact that a subject, more often than not the addressee, did what eventually 
led (or might lead, in vetative uses) to the event referred to. This explains why these mirative meanings often imply an animate and agentive grammatical subject. ${ }^{12}$ Even if the referent of the subject cannot be held responsible for the state of affairs, the speaker will pretend s/he is:

(4) C'est pas vrai... T'es malade - où t'es allé attraper ça ? (quoted by Larreya 2005: 354)

(19) "See, I don't want Mrs Hollidaye to go thinking you're riff-raff. I don't want her to go getting any wrong ideas about what's become of me." (BNC)

In example (4), the addressee is implicitly held responsible for his current illness, whereas no such ascription of responsibility is implied in où tu as attrapé ça?

Despite these common characteristics, there is one striking aspectual dissimilarity between mirative aller and the English constructions. Mirative aller is a modal modifier, which can only encode the initial boundary of a process. It provides no information about the endpoint. Therefore, its complement verb is compatible with any kind of eventuality. By contrast, the binomial phrase and go $V$-ing are two aspectual variants of mirative go. The complements taken by go $V$-ing tend to be verbs of activity and verbs of cognition whereas the binomial phrase is incompatible with verbs denoting cognitive states. The similarity between aller and go may be illustrated by the following translational equivalents:

(25) He remembered Nigger Island as a boy. ... sort of rock covered with gullsstood about a mile from the coast. It had got its name from its resemblance to a man's head-a man with negroid lips. Funny idea to go and build a house on it! Awful in bad weather! But millionaires were full of whims! (A. Christie, Ten Little Niggers, 1939)

Lîle du Nègre. II se rappelait y avoir été dans son enfance. Une sorte de rocher nauséabond hanté par les mouettes, à quinze cents mètres environ de la côte. Cette île devait son nom à sa ressemblance à une tête d'homme...

Bres \& Labeau (2012) show that mirative aller is compatible with inanimate subjects (see one of the instances they quote: L'hiver est dur, cette année, et jamais on n'a vu cette épaisseur de glace au ruisseau; et jamais on n'a senti ce froid, si fort qu'il est allé geler le vent au fond du ciel, hence undermining Larreya's claim that this use necessarily implies an animate and agentive grammatical subject. We may nonetheless counter that the cold is being personified here. 
aux lèvres négroïdes. Drôle d'idée d'aller bâtir une maison là-dessus! C'est horrible de vivre dans un îlot quand souffle la tempête. Mais les millionnaires sont tellement capricieux!

(21) 'You were always good to her, Justin, you know you were. You mustn't go castigating yourself for crimes you didn't commit. (Le Carré, Constant Gardener)

Vous avez toujours été bon envers elle, Justin, vous le savez bien. N'allez pas vous reprocher des fautes que vous n'avez pas commises.

This pair of translational equivalents shows that both go-constructions may render the meaning of mirative aller. But the choice between the two goconstructions is not made at random. It is governed by the Aktionsart of the complement verb. In the examples of our sample, the go $V$-ing construction does not take an event implying an endpoint as a complement, ${ }^{13}$ in contrast to the go and $V$ construction. Vice versa, the go and $V$ construction does not appear with verbs of activity, in contrast to the go $V$-ing construction. The following constructed utterances would have a meaning significantly different from that of the original ones:

(25') Funny idea to go building a house on it.

(21') You mustn't go and castigate yourself for crimes you didn't commit.

$\left(25^{\prime}\right)$ would sound strange if said about a house that has been built, but would be perfectly felicitous in a comment on a process that has actually started. (21') would be construed as a genuine obligation not to carry out a prospective event, whereas deontic modality in (21) is pragmatically interpreted as a rebuke - the speaker blaming the grammatical subject for his self-castigation. (21) could be glossed as follows: "I see you are castigating yourself, but you shouldn't." This aspectual distinction cannot be made in French with aller + infinitive.

\section{References}

Aikhenvald, A. (2004). Evidentiality. Oxford: Oxford University Press.

13 In (17), buy things does imply an endpoint, but the iterative nature of the process, intrinsically linked to the plurality of the object gifts, makes it perfectly acceptable. *Don't go buying this gift would be impossible. 
Bourdin, P. (2003). On two distinct uses of go as a conjoined marker of evaluative modality. In: R. Facchinetti; F.R. Palmer \& M. Krug (eds), Modality in Contemporary English. New York: Mouton de Gruyter, 2145.

Bres, J. \& Labeau, E. (2012). Allez donc sortir des sentiers battus! La production de l'effet de sens extraordinaire par aller et venir. Journal of French Language Studies, published online $12^{\text {th }}$ June, http://dx.doi.org/10.1017/S0959269512000154.

Bybee, J., Perkins, R. \& Pagliuca, W. (1994). The evolution of grammar. Tense, aspect, and modality in the languages of the world, Chicago: The University of Chicago Press.

Celle, A. \& Smith, N. (2010). Beyond aspect: will be-ing and shall be-ing, English Language and Linguistics 14: 2, 239-269.

Clark, E. (1974). Normal states and evaluative viewpoints, Language 50 (2): 316-332.

Collin, C. (2010). GO et l'injonction: le cas de GO AND V, CORELA, Cognition, Représentation, Langage (http://corela.edel.univpoitiers.fr/index.php?id=989)

Damourette, J. \& Pichon, E. (1911-1936). Des mots à la pensée. Essai de grammaire de la langue française, Tome IV, Paris: D'Artrey.

DeLancey, S. (2001). The mirative and evidentiality, Journal of Pragmatics 33: 369-382.

Flydal, L. (1943). Aller et venir suivis de l'infinitif comme expressions de rapports temporels, Oslo: J. Dybwad.

Forest, R. (1999). Empathie et linguistique, Paris: Presses Universitaires de France.

Giancarli, P-D. (2006). Le Futur Périphrastique modal français d'« allure extraordinaire » (assertif, et interrogatif, impératif) et ses traductions en anglais, Anglophonia 20: 149-179.

Guentchéva, Z. (1996). Introduction. In: Z. Guentchéva (éd.), L'énonciation médiatisée, Louvain-Paris: Peeters.

Lansari, L. (2009). Les périphrases verbales aller + infinitif et be going to, Paris: Ophrys.

Larreya, P. (2005). Sur les emplois de la périphrase aller + infinitif in: H. Bat-Zeev Shyldkrot \& N. Le Querler (éds), Les Périphrases verbales, Amsterdam: John Benjamins, 337-360.

Lazard, G. (2001). On the grammaticalization of evidentiality, Journal of Pragmatics 33: 359-367. 
Paulin, C. (2006). Etude sémantico-syntaxique d'unités polylexémiques dont le noyau est go: la construction du sens par le co-texte. In: G. GirardGillet (éd.), Aux marges du texte. Texte et co-texte, CIEREC Travaux 128, Publications de l'Université de Saint-Etienne, 15-32.

Peirce, C.S. ([1893-1913] 1998). The Essential Peirce, Selected Philosophical Writings, volume 2. Peirce Edition Project. Bloomington and Indianapolis: Indiana University Press.

Rocq-Migette, C. (2009). Using the adjectives surprised/surprising to express epistemic modality. In: P. Busuttil; R. Salkie \& J. van der Auwera (eds), Modality in English, Theory and Description, Berlin, New York, Mouton de Gruyter, 223-235.

Schrott, A. (2001). La modalisation d'une forme temporelle: le futur périphrastique et l'allure extraordinaire. In: P. Dendale \& J. van der Auwera (eds), Les verbes modaux, Cahiers Chronos n ${ }^{\circ} 8$, Amsterdam: Rodopi, 159-170.

Spears, A. (1982). The Black English semi-auxiliary come, Language 58 (4): 850-872. 